\section{AN ARCHITECTURAL ANALYSIS OF THE MON COMMUNITY IN PHRA PRADAENG, SAMUTPRAKARN}

\section{Pussadee Tiptas ${ }^{1}$}

The Mon are an ethnic group in Thailand. Most Mon communities are located on river banks and they have, to a certain extent, preserved traditional life styles. This is a study of the Mon community in Pra Pradaeng, Samutprakarn, focusing on its residential and religious architecture.

\section{Location and Environmental Settings}

The Mon community in Phra Pradaeng District lives in 16 villages of 4 tambons (subdistricts). Of these, 15 villages are located on the west bank of the Chao Phraya River in Tambon Bang Pung, Tambon Talad and Tambon Song Kanong. Only one village, in Tambon Bang Ya Prak, is located on the east bank. Most Mon communities live along a river. This characterizes early settlement in the town of Nakhon Khuen Khan or Phra Pradaeng at present.

There are many villages on Klong Lad Luang (see Figure 1) namely, Baan Saphan Chang, Baan Ta; Baan Ha Roen, Baan Veharao, Baan Dang, Baan Kong Kang and Baan Chiang Mai. The general condition of these

\footnotetext{
${ }^{1}$ Professor, Department of Architecture Faculty of Architecture Chulalongkorn University
}

villages has remained unchanged and it is possible to commute between them by waterways. On Klong Lattanong there are Baan Tamang and Baan Tong U. Baan Tur and Baan Jung Be are on the south of the Chao Phraya. Baan Among is on the north side where the locality has changed dramatically with a steady decline in the Mon population and poor housing conditions. Baan Kanong, which adjoins the Chao Phraya in the north, still maintains its traditional locality and buildings.

Further up from Baan Song Kanong, Baan Chae and Baan Rong Kleng are in the urban center, mainly serving as commercial, school and government service centers. Baan Doeng Hamok is the only village on the east bank of the Chao Phraya. Inland from the river, this urban settlement is dense with factories located in the surrounding areas.

\section{Family and Kinship}

The Mon living in the 16 villages of Phra Pradaeng are the descendants of the Raman from Pathum Thani. Led by Phraya Jeng, these people migrated to Thailand during the Thonburi period. Later in the reign of King Rama II, they provided labor for founding Nakhon Khuen Khan or Phra Pradaeng. The new settlement was named 
after the former name of the Mon township. Most of them were soldiers and their families, but later on they mixed with other local ethnic groups. At present, the Mon villagers constitute 60 percent of the total residents. Half of them claim that their ancestors were from Pegu in Mon state.

Our survey reveals that about 72 percent of the Mon families have 3-8 members, a relatively small family size. They are extended families like Thai families (i.e. married son or daughter staying with his or her parents) comprising 2-3 generations. About 45 percent of the Mons serve in government or state enterprises, followed by other jobs such as, rice growing, trading and handicraft making. The people's religion is Buddhism serviced by 10 wats (temple). Most of the Mons are religious as can be seen in their regular merit making, almsgiving and involvement in all religious occasions.

\section{Beliefs and Taboos}

Elderly Mons believe in destiny and taboos as well as old cultural traditions and beliefs. The instances of these include not keeping an altar or Buddha image in the house; not bringing in sculptures of certain animals; e.g. pigs, turtles and elephants; not allowing pregnant women from other families or children with 'juke' hairstyle to stay overnight, etc. The north, south and east are their compass points of virtue to which bed, front staircase, main entrance, as well as the face of the statue of the Lord Buddha, will be directed.

Most Mons, accounting for 80 percent, in Phra Pradaeng, worship house spirits, in the tradition of their ancestors. The eldest son inherits the ritual of receiving a gold ring decorated with red-colored gemstones and traditional costumes - all of which must be well kept. The Mons also worship sacred objects as symbols of the status of a 'god father' or god image originating from the Mon township. There are 11 spirit houses respected by the villagers. One spirit house may be the center for several villages, or possibly there are many spirit houses in one village, and some villages have both god father and god mother images.

\section{Religious and Traditional Customs}

Religious customs and traditions in the Mon community have now become less important due to pressure of time and financial status of the new generation. Marriage to other ethnic groups is another cause. However elderly people still keep the Mon traditional customs although some rituals may be less delicated. One remaining is ghost dancing to apologize for their offenses or to pay homage to the god father image after the Song Kran festival.

Customs related to child birth, too, have attracted less interest since hospital services have become increasingly popular. Only 22 percent of the Mons arrange a head shaving ceremony for their new born child. Ordination is similar to the Thai culture except for some details. The marriage ceremony is similar too but the Mons do not practise religious almsgiving. Ceremonies related to Mon funerals are mostly for abbots, senior monks or respectable elders and involve laying the dead on rattan tables instead of using coffins or alternatively using coffins of rectangular shape. Dancing is performed 
before the day of cremation. A dead senior monk's coffin is topped by an elegant canopy in the form of a palace.

Religious and traditional customs performed now include, for instance, honey almsgiving, Devo almsgiving and boat racing. The most important and unique Mon festival is Song Kran which is characterized by live fish and bird releasing and playing the traditional 'saba' game. The game is so well known that 87 percent of the Mons in Phra Pradaeng are able to play. The custom of giving Song Kran rice to monks or relatives is rarely seen now. Now, only 17 percent are able to sing 'tayae mon,' and, only about 17 percent join in boat racing.

\section{The Changing of Attitudes in the Community and Its Impact}

According to the Mons' point of view, the community in Phra Pradaeng has steadily changed over the past 20 years. It can be concluded that customs, folklore and traditional games previously performed are likely to fade away. Some patterns have been altered or adapted in line with present economic conditions. With regard to the Mon language, fewer and fewer people are now able to read and write Mon except for some monks and elder people who learnt it before. The new generation does not use the Mon language since teaching and speaking it is rare.

Phra Pradaeng has experienced economic growth in the past 20 years. Land is increasingly used for manufacturing, commercial and farming activities. However, the Mon population movement is relatively static, most of it of a temporary nature for education or work purposes.
On the other hand, there has been an increase in the number of other ethnic groups moving into the community particularly to the commercial and industrial areas located nearby.

The people's opinion is that now their community is more developed than in the past. Changes are gradual, mainly in public infrastructure, i.e. roads, ferries piers, alleys, pavements and bridges. Communication in the district has become more efficient. The community is growing and building has expanded so much so that green and public areas have become more scarce. Thai style housing is disappearing. Most houses have fences, rarely seen in the past, to protect the property. Nevertheless, the people assert that local authorities have now provided better services in public health, sanitation and facilities for traditional ceremonies.

Concerning changes caused by pollution and its environmental impact on the community, the people observe that there have been changes in the past 20 years. Although there is no heavy industry located in the village causing direct impact, 47 percent of the people stated that they were affected by air pollution, smoke and dust. The majority of them live in Baans Song Kanong, Rong Kleng and Among of Tambon Song Kanong on the opposite side of Tambon Samrong Tai where industries such as iron making, and palm oil manufacture are located. Baan Doeng Hamok of Tambon Bang Ya Prak has experienced a similar situation because of several heavy industries in the area.

Toxic elements on the roofs have also affected the use of water from rainfall. Presently, about 37 percent of people in the Mon village no longer use rain water 
since the expansion of factories in the surrounding area. Flooding is another consequence of the physical changes due to the greater number of factories. About 23 percent of the people suffer from flooding problem.

It can thus be stated that a quarter of the Mon villages are affected by pollution caused by the factories. Although they are not located in the community, wind direction and close proximity make it possible for dust to be blown, and for smoke and smells to disturb the people. Tambons Song Kanong and Bang Ya Prak are more heavily affected when compared with Talad and Bang Pung which are more distant and not in the path of the prevailing wind.

\section{Physical Characteristics of the Residential Architecture in the Mon Community}

Our analysis of Mon residential architecture based on interviews and field surveys led us to the conclusion that the early settlements were scattered along rivers. Most houses are simple wooden structures - a kind of typical Thai house, unlike those in their homeland. The broad side of the house faces the river so that it can resist the river wind. The narrow side is placed at a 90 degrees angle to the river in an east-west direction. Most Mon houses ( 84 percent of the total) are of this design which protects the house from heat while allowing the occupants to enjoy breeze and to place their beds facing the south according to traditional practice (see Figure 2).

\section{Mon Housing Design}

When an old Mon house became dilapidated, it was renovated with some new materials. In many instances, a new house was built to replace the old one. We found that the houses built in a later period, i.e. by the reign of King Rama V, were the most numerous. Most of these are of traditional Thai design, wooden structures on stilts with palm leaf or tiled roofs, depending on the owners' financial status. Most houses maintain the original single structure although there might be some extension, e.g. a cover over the terrace to maximize the use of the space. An additional house may be built beside or behind the old one for increased convenience and to house the increasing number of family members. This kind of housing is the most popular, representing 69 percent of the total. The members of the household may range around 3-8 persons indicating a relatively small family size. In addition to that, financial conditions usually do not allow them to extend the compound or the size of the property. Land size per family is not very large. About 66 percent of the people own a block of 24-100 square wa. This group probably consists of those who settled earlier in Thailand and were permitted by the King to own some land. For those better - off families with a large number of members, the house is a double unit or a complex. The block of land may be more than 300 square was up to 3 rais per family. But this category is less numerous.

\section{Interior Functions}

The interior facilities of a Mon house now are no different from those of a typical Thai house or from the traditional style. 
The bedroom usually occupies 3 bays of column. In general, the room is not strictly partitioned. A long cabinet is placed on the innermost part to separate a daughter's bedroom or the owner's sanctum. The front has a portico, a multipurposed space used for meeting visitors, dining and relaxing. This portico is accessed by an open terrace. The broad side of the house at the back of bedroom portion may be used by a married daughter or for other uses. This kind of design represents about 57 percent of the total Mon houses. Also, about 81 percent have a kitchen on the upper floor of the house. This is for the convenience of leading to the dining room which is located in the house too. The bathroom, on the other hand, is located below or separated from the main house in 61 percent of the Mon houses. In the past, the ground-floor was used for leisure, housework or playing traditional games during the Song Kran festival but nowadays it is used less frequently due to flooding (see Figures 3 and 4).

The house building ceremony is similar to most rural Thai practice. This includes the ceremony for erecting the main post on top of which a red-colored gemstone is placed as a Mon symbol. The main post is usually at the right corner or the middle of the bed chamber. The post faces east according to traditional belief. Nevertheless, nowadays the construction of new houses is decreasing due to limited financial resources and the ceremony has now been made simpler for the builder's convenience.

\section{Architectural Components}

Our field survey reveals that almost all Mon houses are of wooden structure.
Pillars are of Thai style. Either a Thai style roof with a gable and eaves is employed to protect the house from the bad weather. Materials used for roofing can be palm leaves, zinc plates and tiles depending on owner's financial status and the period of its construction or renovation. The detailed designs of wooden walls in older house are different from those of the newly-built or renovated ones (see Figure 5).

Windows and doors are similar to those of Thai houses. Most Mon houses have a solid, wooden door leading into the house; the lock is also made of wood. Renovated houses may have in addition wooden or iron bars to pervent burglary. Some may have altered windows for ease of opening to outside and in order to attach mosquito nets. There is a partition between the bedroom space and the portico, enabling connection between the inner and outer areas. Usually there is a carved wooden ventilation point above the partition.

Concerning flooring, about 65 percent of Mon houses use wooden planks laid along the length of the house. This is different from the older design where the planks were laid transversely due to the scarcity of long planks. A ceiling is usually erected above the portico but about 84 percent of the surveyed houses did not have a ceiling over the bedroom space, thus allowing for greater air circulation and the cooling of the room.

A wooden stepladder is usually attached with a wooden rail for support. Some low houses do not have such a rail. The front stairs face east and north, a recent tradition similar to Thai houses. Nowadays, 45 percent of Mon houses have spirit houses 
within their compound, a practice previously not existent among the Mons.

It is evident that Mon houses share similarities to Thai houses. The functions of the housing space have remained the same since the Mon first settled here although there may have been some extension to accommodate their contemporary needs.

The Mon's customary beliefs concerning housing have changed and are less strict than in the past. Some prohibitions are less strict and have been altered in line with the times and are in keeping with social, economic and community changes since the Mon have now increasingly mixed with other ethnic groups.

\section{Physical Characteristics of the Religious Architecture in the Mon Community}

\section{Location and Site Planning}

The religious architecture in the Mon community in Phra Pradaeng is generally similar to that of a Thai temple. It is divided into three parts, namely, Bhudhavadh, Sanghavadh and Kharavadh (Laymen). These are areas for conducting religious ceremonies. Each of them is separate. This arrangement is different from the one in Mon and Burma or from Shan temples in the north of Thailand where they are grouped in one structure.

Generally the Bhudhavadh area of a Mon temple in Phra Pradaeng is composed of ubosoths, viharns, chedis and Sao-hong; however, the viharn is not regarded by Mons as an important structure for Mon temples. Hence, there are only four Mon temples where viharns are situated in Bhudhavadh group. Most of them are old ubosoths which later were transformed to be utilized as viharns after the completion of the new ubosoths. Half of the Mon temples have Mon chedis which are circular or octagonal in shape and the other half have Sao-hongs which are regarded as the symbol of Pegu (Hongsawadi) the ancient Mon capital. Mon ubosoths in Phra Pradaeng are built along the eastwest axis with their front parts facing the east. However, this positioning is not definite since sometimes the location of the site and the entrance to the temples dictate the orientation of the ubosoths.

The Sanghavadh part of a Mon temple is composed of Sangha-gudhis, Ho-shant or a chanting hall and a bell tower. Living quarters for Sangha are mostly single gudhis which are wooden or masonry (brick work). They are flat or cell type gudhis which normally are constructed around the chanting hall. Half of Dhamma teaching or Pariyati-Dhamma teaching of Mon temples in Prapradaeng is done in the schools of Pariyati-Dhamma.

Sala-Karapareint, cemeteries and salas for merit making are included in the Layman part. One can gain access to this area as in a conventional Thai temple. Sizes of Mon temples are from 3 rais up to 32 rais and large ones mostly include local primary and secondary schools within their compounds.

Half of the Mon temples in Phra Pradaeng were mainly constructed during the reigns of King Rama II, and King Rama III. Some were built in the reign of King Rama I. However, a few of them were constructed before Ratanakosin Period and during the reign of King Rama V. Half 
of the Mon temples were constructed by Mons and the rest are Mon temples which were renovated by King Rama II and have been settled by Mon sanghas or have been supported by Mon local communities.

The lay-out of Mon temples in Phra Pradaeng is not systematic nor does it strictly rely on definite criteria. The position of Bhudhavadh, Sanghavadh and layman quarters is not identical for every temple, however; each quarter or group is clearly divided from the others. Most of the temples, that have ubosoths and viharns, which are normally positioned parallel to each other and old ubosoths which have been transformed to be utilized as viharns. Also, there is no particular system that can characterize the layout of chedis. Therefore, there are chedis situated in the front, along the side and behind the ubosoths or even between ubosoths and viharns. The positioning of Sao-hong is relatively identical and they are in front of the temples, facing water. Some Sao-hongs are used as flag poles or as electric power poles.

\section{Architectural Aspects}

The Architecture of Mon temples is similar to that of Thai temples where bricks are used to construct rectangular-shaped ubosoths. The measurement of these ubosoths ranges from 3 to 7 bays of columns. Most of ubosoths have front and back corridors and each end is connected with steps for entrance and exit. Others have corridors around. There is only one ubosoth with no corridor.

Generally, Mon temples have presumedglass walls or Kampaeng Keaw and each of them has one entrance to the ubosoth area. Some may have arch ways and others may not. Se-ma stones marking the ubosoth's boundary can also be found in Mon temples as well as Thai temples. They are similarly positioned in that Se-ma stones are placed at all four corners of the ubosoth area and the middle Se-ma stone stand between the two corners. Sema stones of some temples are situated on the corridor of the ubosoth or at each corner of the base of the ubosoth.

The Architectural components of Mon temples in Phra Pradaeng are similar to those of Thai temples, for example, 2-3 levels of Thai style decreasing roof plane (see Figure 6). There are also 2-3 levels of eaves which are supported by wooden brackets. The gable end is usually decorated with traditional than elements. Only one Mon Temple in Phra Pradaeng has no portico and its gable is decorated with stucco in floral design with Mon lettering at the center. Wat Mok's gable is plain with stucco decorated with ceramic mosaics.

The Ubosoth gable is made either of wood or stucco decorated with gold leaf and glass mosaics. Designs normally found on the gable include the Indra God on an Erawan elephant; traditional Thai as well as Mon elements such as twin Mon swans on a Buddha Image. In Wat Songtham which is a temple under royal patronage Thai mythical animals and a royal tier umbrella appear on its gable.

Door and window panels of Mon temples in Phra Pradaeng are of moulded cement with smooth rims or arch ways with 2 panes of Ban-talaeng or monthop arch way with styles on it panels. Modified doors and windows have supporting poles on the sides and western triangles made of cement on top. 
The ceiling of an ubosoth both inside and outside is painted red or red-brown. Some are painted golden or red-brown with clusters of stars made from carved wood and gilded. The floor of the ubosoth of each Mon temple is normally decorated in various styles depending on how wealthy the community was during the time it was constructed. There are cement tiles, polish ceramic tiles and even marble tiles for the ones that were constructed in the later period.

To sum up, most of the Mon religious buildings in Phra Pradaeng are similar to Thai religious ones due to the fact that both Mons and Thais are Buddhists. Mons in Thailand adopted Thai temples as models to build their own temples without taking account of the Mon patterns in the Mon area, of Myanmar. Therefore, at present only two Mon temples in Phra Pradaeng are of Mahayana Bhuddhism, the rest are of Theravada.

Aside from having abbots as Mons or having preachings in Mon language for sometimes, the physical structure of the temples symbolically represents the Mon temple. For instance, the circular-shaped or octagonal-shaped chedis which were the imitation of Pra-Mootao Chedi in Pegu, Myanmar. The original Mon chedi normally does not have much decoration or is similar to Chavaedagong chedi that the Burmese have adopted and modified by adding 4 little chedis on all 4 corners of the podium.

Another prominent physical feature of the Mon temple is the Sao-hong which can be seen clearly from far distance. The design of hong or swan is a symbol of Pegu which was an ancient Mon capital. Therefore, this symbol is normally found in the decoration of the gable front of an ubosoth, and on the door and window panels.

\section{Conclusion}

This empirical study of the Mon community in Phra Pradaeng where there are 16 Mon villages indicates that increasing interactive association among members of the Mon community with people outside has led to various changes in and has had an impact on their cultures and beliefs. As the Mon community was enveloped by other communities which had different social and cultural backgrounds and trading and industrial areas, their culture was influenced by those different forces. This resulted in the diminishment of the Mon culture and its assimilation into surrounding communities. To conserve and to promote Mon culture, I recommend seven approaches:

1. Encouraging the Mon people in Phra Pradaeng to have roles in various cultural activities, such as the establishment of an association of Thai-Raman, Prapradaeng branch, the membership of which is a must for local Mons. The association should introduce various cultural promoting activities, namely, organizing Mon cultural activities, giving education on Mon culture through mass media; newspapers, radio and television as well as through other publications, tapes and video tapes of various Mon culture.

2. Promoting Mon culture in the area of architecture. This is another measure needed to be addressed by concerned parties. The increased number of industrial plants in Phra Pradaeng obscures most of the 16 Mon villages, some of which, can only be seen from a distance such as the villages 
located along remote canals in the area; Wae-Harao village, Baan Haruen and Baan Ta on the side of Klong Lad Luang canal in Bang Pung District and Baan Song Kanong village on the Chao Praya River and covers some areas in Baan Thoung Kanong District.

These three villages in Bang Pung District consist of Mon houses which are similar to Thai classical houses in the central region. These villages are located along Klong Lad Laung Canal. Each of them has its village name posted in Mon language. Each village has its village spirit house where villagers annually organize certain ceremonies to show their respect. Therefore, the villages' way of life and culture, which is not much disturbed or influenced by different cultures from other Thai neighboring communities, should be conserved as they are or as they used to be. A zoning system to keep off the growing of industrial area is a need to be considered by concerned parties.

3. Turning Baan Thong Kanong where there is not much change in terms of architecture, into a conservation area. It can be clearly seen that there are a great number of typical wooden Mon style houses in this community; each is connected by narrow walk-ways and wooden bridges. Therefore, only tricycles and motorcycles can access the area. There is no access for large vehicles as is the case in nearby industrial areas.

The promotion of various Mon cultural dances and ceremonies is needed in Thong Kanong village. One of the distinctive cultural activities is bamboo dancing or sa-ba dancing which can be seen during Songkran festival. There are a number of sa-ba areas in Thong Kanong village which are frequently attended by members of the village or from nearby Mon villages. These sa-ba clubs, which are well decorated and are full of talented dancers, are appreciated by other nearby Mon villages for their high quality performances. It is necessary to restore and to revive certain ceremonies which existed in the past such as "kao-chae" cooking during Songkran festival, "gayasart" and "kalamae" cooking and the playing of Ta-Yae Mon, Mon rong-hai, Mon musical play and spirit dancing. Details of these cultural activities should be publicized to attract the attention of people in Samutprakarn province and other nearby provinces.

4. Promoting certain Mon temples in Phra Pradaeng such as Wat Thong Tham, Wat Arsa-Songkram, Wat Klang and Wat Kae temples as focal points to launch cultural and religious activities such as "Tak bat te wo" ceremony and Tak bat nam pueng; offering food to sanghas; hang hong march; Songkran rice delivering to sangha ceremony and demonstration of sa-ba dancing by senior Mons as well as Mon funeral ceremony of highly respected deceased persons or sanghas. These ceremonies should be documented for the sake of coming generations.

5. In terms of architectural design, it is important to promote the conservation of the typical Mon houses. They can be registered with the Association of ThaiRaman Information. Background, history, pictures and plan of each house should be recorded by concerned parties.

6. It is necessary to recognize the importance of Mon architectural characteristics. For example Mon chedi, Sao Hong and traditional decorative elements. Conservation and restoration 
of these features should be encouraged. The Association of Thai-Raman and the religious committee should be responsible for the establishment of certain measures to restore them. For instance, the promotion of the re-painting and maintenance of Mon chedis. Zoning systems should be implemented to prevent the construction of new structures which are not physically relevant to Mon chedi.

7. Samutprakarn city council and the Ministry of Industry should take measures to control water and air pollution from industrial areas into nearby living areas. Government authorities must regularly inspect those industrial plants. Zoning is also needed to counteract damaging influences on Mon communities such as the villages in Baan Pung and Thong Kanong Districts and other religious sites.

\section{Glossary of terms}

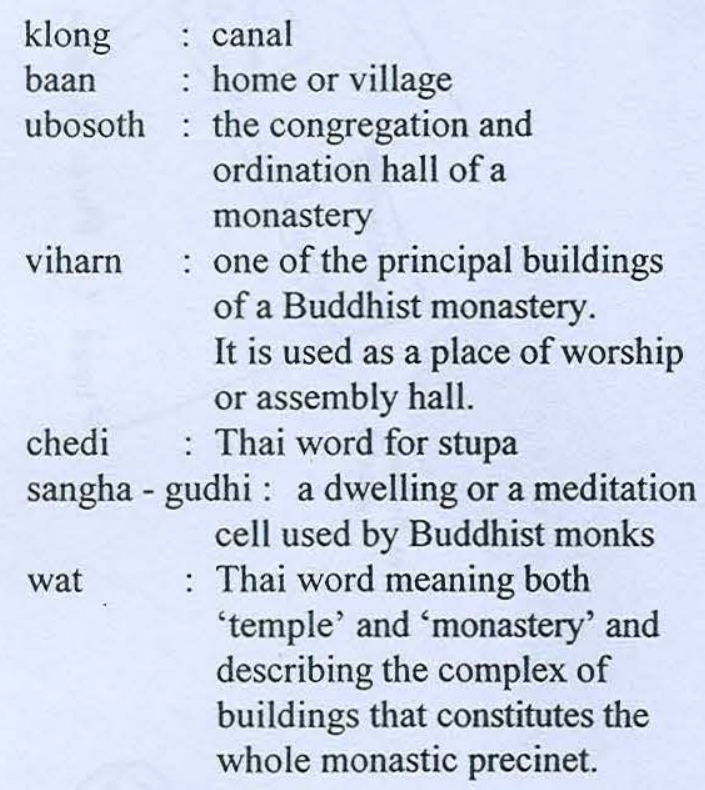




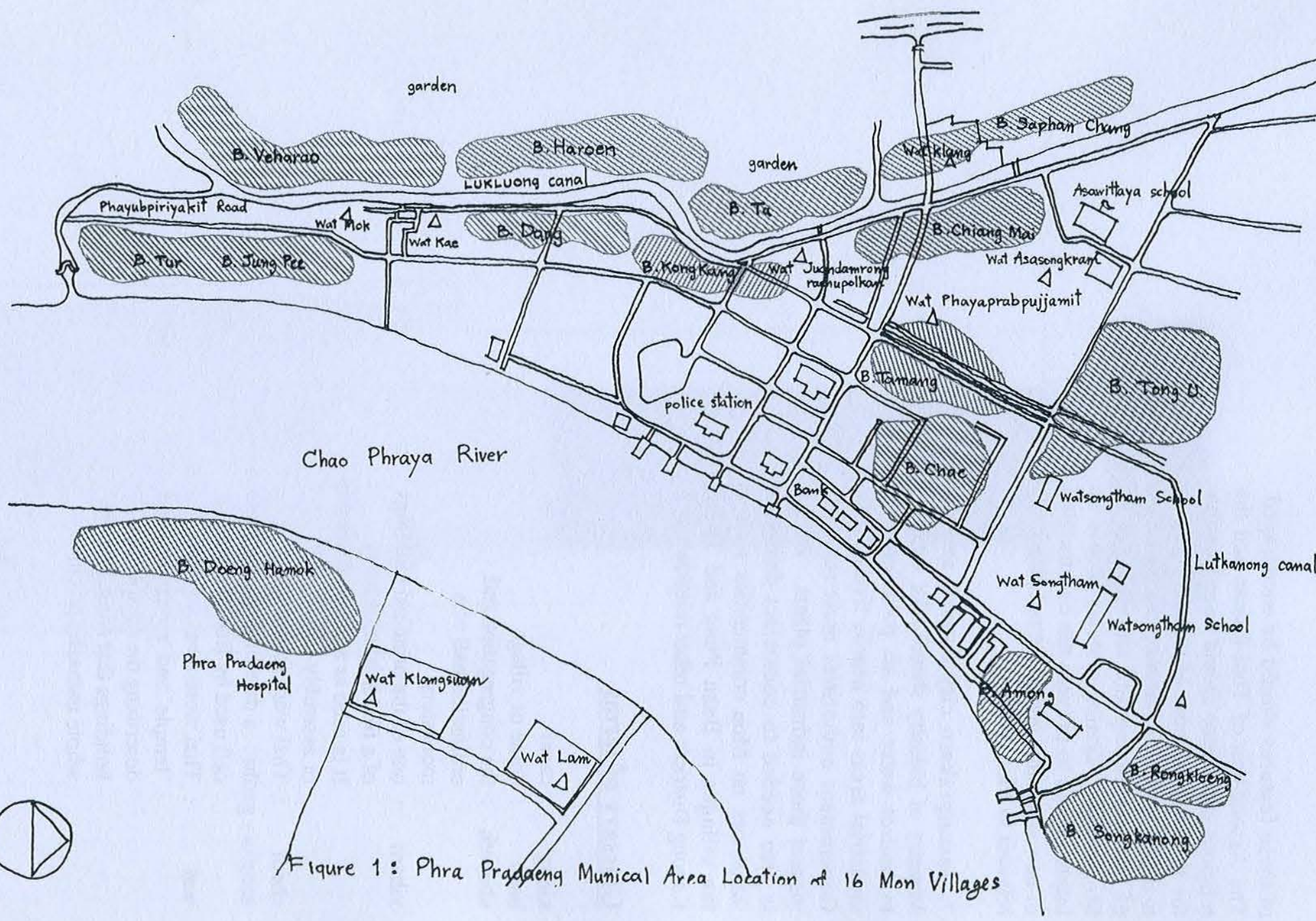




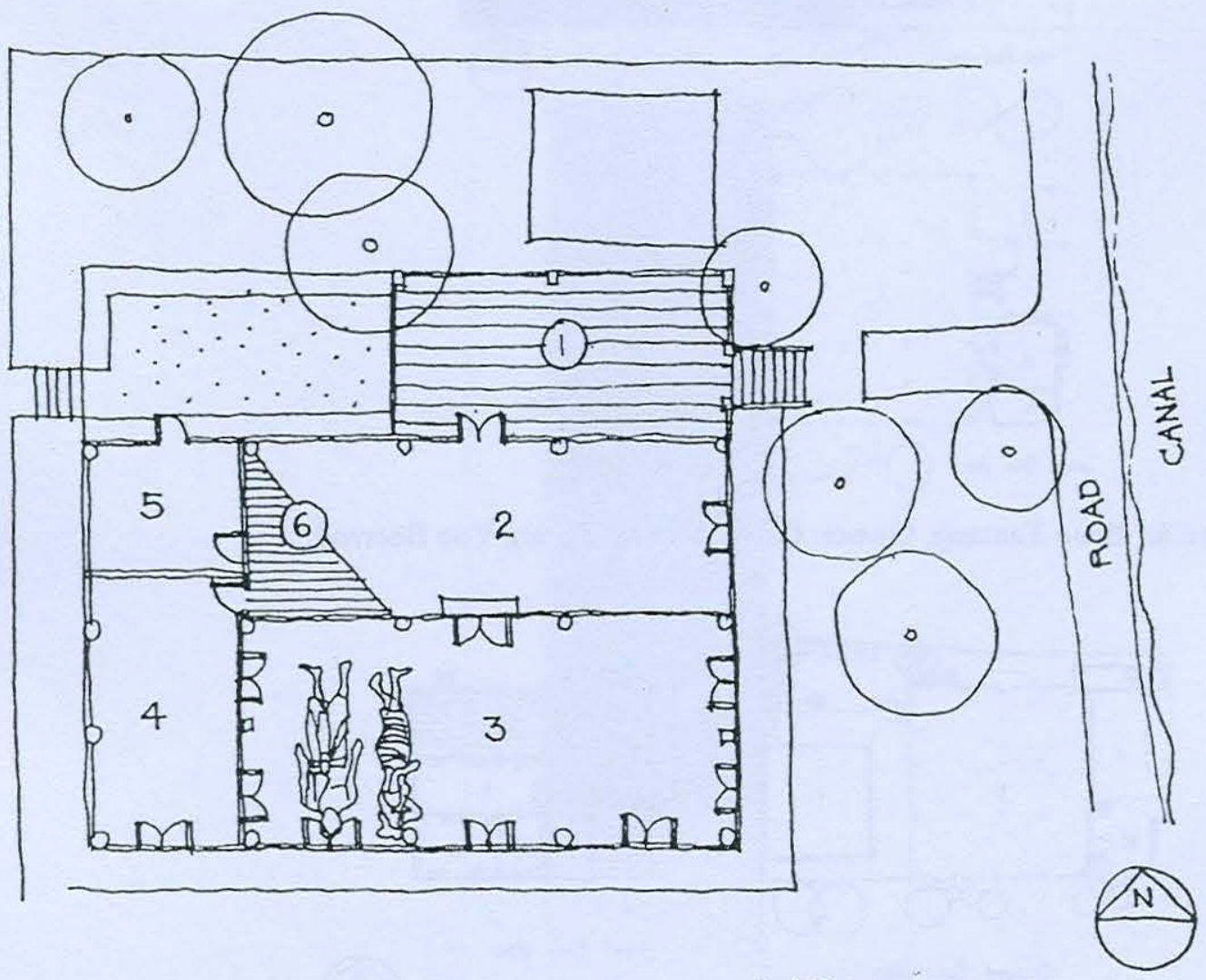

1. Terrace

2. Multi - purpose

3. Bedroom

4. Bedroom

5. Bathroom

6. Kitchen

Figure 2: House in traverse to river, orientate east-west. Bed directs to south direction, Entry to the east. (Baan Chiang Mai, Owner: Grand Mother Thong Yoo). 
MANUSYA: Journal of Humanities Vol. 1 No. 21998

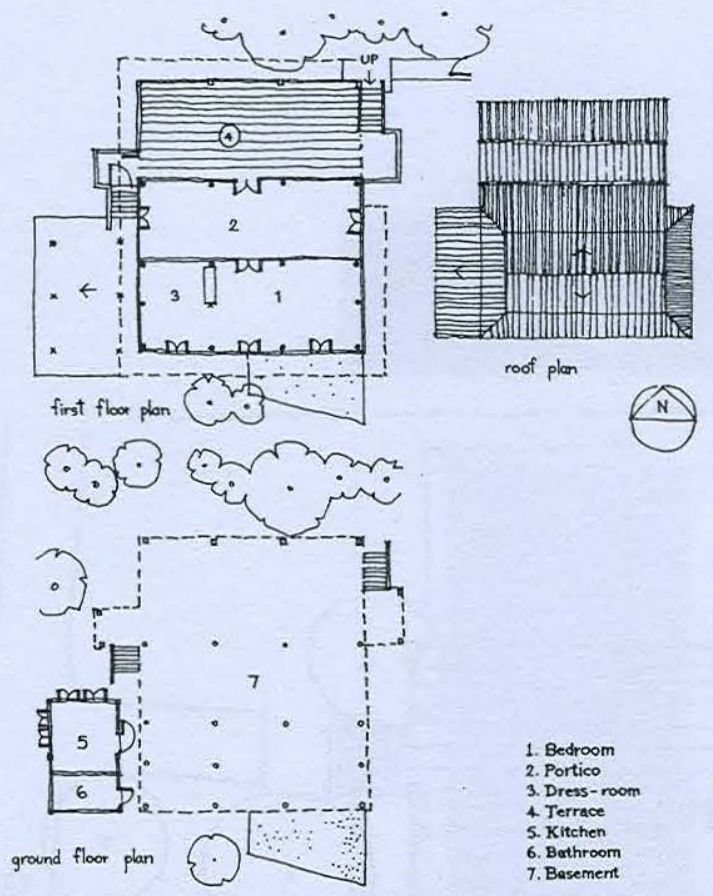

Figure 3: Baan Tamang, Owner: Grand Mother Thong Yoo Beerrod.

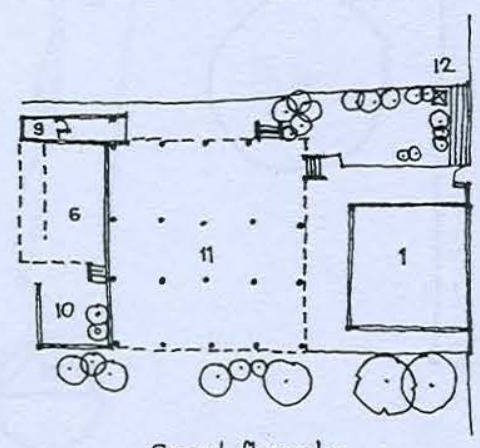

Ground floor plan

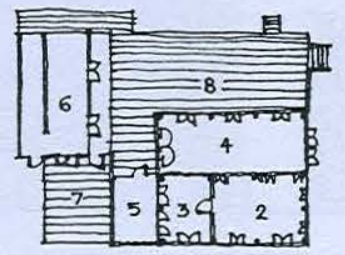

First floor plan

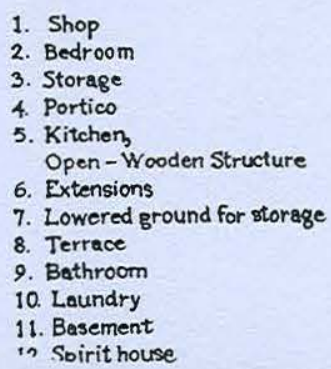

Figure 4: Baan Doeng Hamote, Owner: Lamoon Krengkapan. 


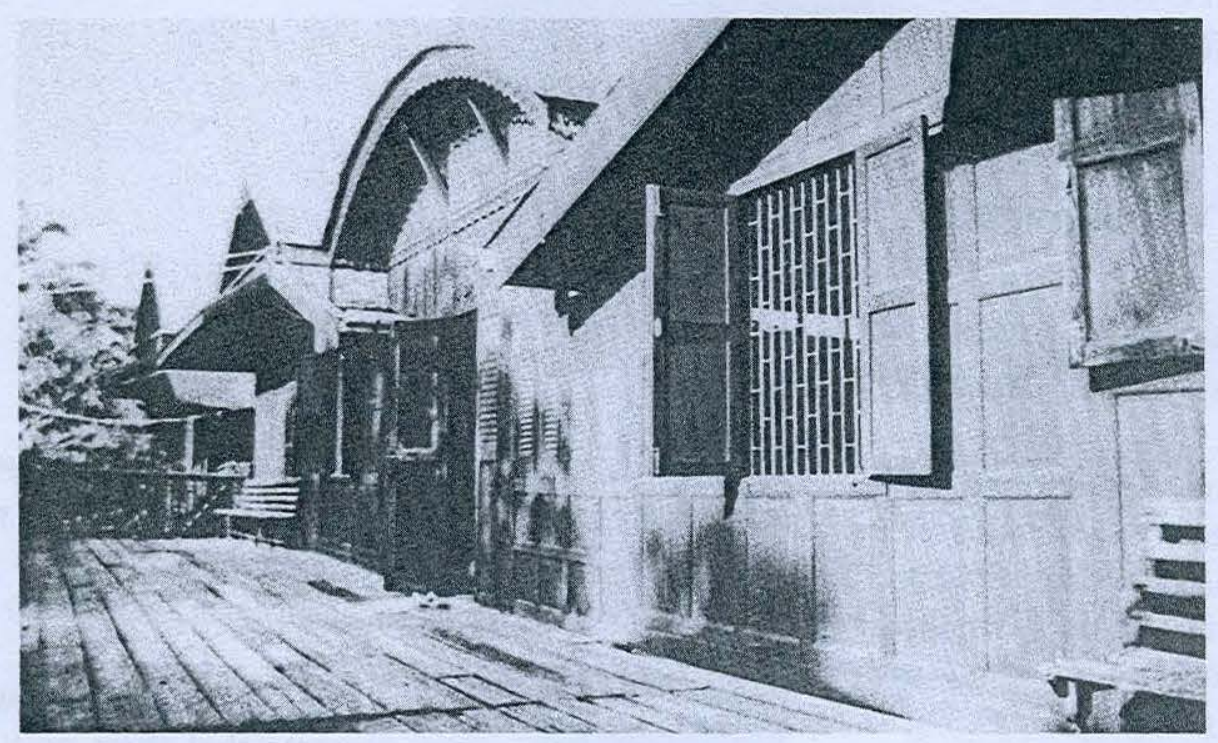

Figure 5: A typical Mon house. The picture shows terrace, and two bedrooms connected with covered veranda.

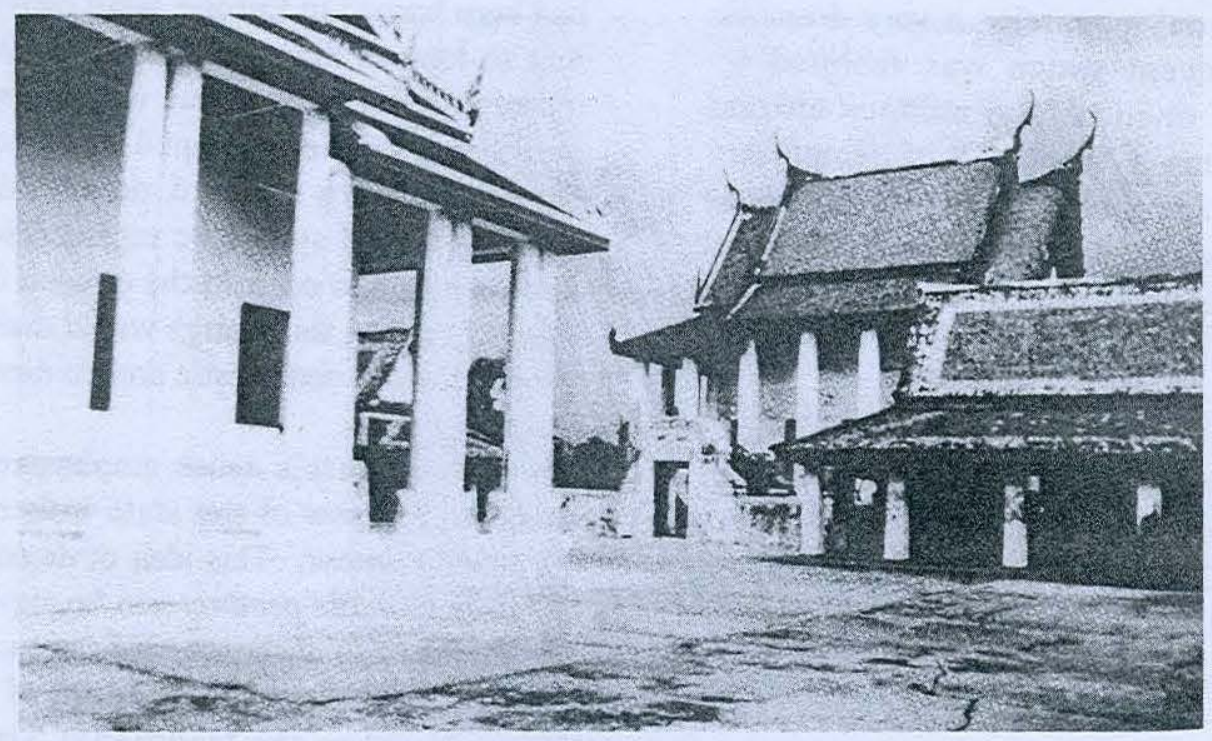

Figure 6: The ubosot and the vihara of Wat Songtham, Phra Pradaeng. 